\title{
Effect of dolomitic limestone and organic fertilizers on some physical-chemical properties and the structure of a Vertisol
}

\author{
Pedro Cairo Cairo ${ }^{1 *}$, Joaquin Machado de Armas ${ }^{2}$, Bladimir Diaz Martin ${ }^{1}$, Oralia Rodriguez Lopez ${ }^{2}$ \\ ${ }^{1}$ Universidad de Atacama, Centro Regional de Investigación y Desarrollo Sustentable (CRIDESAT), Copiapó, 1532000 \\ Chile \\ ${ }^{2}$ Universidad Central de las Villas, Facultad de Ciencias Agropecuarias, Centro de Investigaciones Agropecuarias, Santa \\ Clara, 54830 Cuba
}

*Corresponding autor: pedro.cairo@uda.cl; pedro.cairo.c@gmail.com

\begin{abstract}
The application of natural mineral and organic fertilizers can increase soil productivity. The work was carried out in Vertisols sugarcane areas on the North coast of the province of Villa Clara, municipality of Sagua la Grande, Cuba, with the objective of assessing the effect of dolomitic limestone and organic fertilizers on some physical-chemical properties of a Vertisol. An experiment was conducted with dolomitic limestone levels and combinations of organic fertilizers ( $4 \mathrm{t} \mathrm{ha}^{-1}$ compost, $15 \mathrm{t} \mathrm{ha}^{-1}$ sugarcane filter cake) and fertilizers (NPK). The design used was stripe blocks. The soil analysis data used at the depth of 0-20 and 20-40 cm were at 8, 19 and 36 months after application of the treatments. The following indicators were evaluated: structure factor, permeability, stable aggregates, plasticity, $T$ value, and exchangeable cations. The $\mathrm{Ca} / \mathrm{Mg}$ ratio reached a maximum value of 2.58 , which shows in the effect of the treatments on the interchangeable cations. Dolomitic limestone and its combinations with organic fertilizers showed significant positive effects on soil structure and consistency, both in the surface layer and in the subsoil, with residual impact over time up to 36 months. The results obtained showed a change in the category of structural indicators from regular to excellent (permeability 1.50-2.40) and from plasticity to moderately plastic (Plastic index 36.64 -13.72).
\end{abstract}

Keywords: consistency, dolomitic limestone, organic fertilizers, structure, Vertisol.

Abbreviations: Log $10 \mathrm{~K}$ _ Permeability coefficient; SA_Stable Aggregates; SF_ Structure Factor; LL_ Liquid Limit; LPL_ Lower Plasticity Limit; PI_Plasticity Index; DL_ Dolomitic Limestone

\section{Introduction}

In Cuba, there are large reserves of non-metallic minerals: zeolites, phosphate limestones, bentonites, carbonates, dolomites, dolomitic limestone, potassium tuffs, which are taxed in agriculture and can, provide fertilization and improvement alternatives in order to achieve more favorable conditions for the soil and crop development (Velázquez, 2013). Numerous researchers have highlighted the importance of dolomite and dolomitic limestone in the regulation of fertility of acid soils: it reduces the toxic effect of $\mathrm{Al}, \mathrm{Fe}$ and $\mathrm{Mn}$ and increases the solubility of $\mathrm{P}, \mathrm{Mo}, \mathrm{Ca}$ and Mg (Gina and Nani, 2013; Ayodele et al., 2014; Damrongrak et al., 2015; Nazrul and Khan, 2016; Nazrul, 2018). Other research has studied the combined use of dolomite and Biochar with very positive effects in reducing the emission of $\mathrm{N}_{2} \mathrm{O}$ and $\mathrm{CO}_{2}$ in acidic soils (Shaaban et al., 2017; Oo et al., 2018). On the other hand, there are very favorable antecedents on the use of minerals rich in calcium and magnesium in soils with physical limitations and high natural fertility such as Vertisols, which can be of great practical and economic interest (Lugones et al., 1996; Cairo et al., 2017; Cairo and Reyes 2017; Cairo, 2018). The quality of Vertisols is very limited due to problems of structural degradation, acidification processes due to improper use of fertilizers, compaction due to the continuous use of mechanization in sugarcane crops (Hernández et al., 2015; Cairo et al ., 2017). These soils are extremely plastic and poorly drained, with high water absorption capacity and poor waterair distribution. As the substrate deepens, the air is smaller, so that the roots of the cane only develop to a depth of $25 \mathrm{~cm}$, resulting in less growth and yield of the crops (Vidal et al., 2006; Hernández et al., 2015). The objectives of the research are aimed at assessing the effect of dolomitic limestone and organic fertilizers on some physical-chemical properties and the structure of a Vertisol.

\section{Results and Discussion}

\section{pH and ion exchange}

The analysis of the state of the absorbent complex after the use of dolomitic limestone and its combinations with organic fertilizers showed in Table 1 the different trends of the 
indicators that characterize it. The $\mathrm{pH}$ in both $\mathrm{H}_{2} \mathrm{O}$ and $\mathrm{KCl}$ varies from mildly acidic to neutral or slightly alkaline. Dolomitic limestone and organic fertilizer influenced not only the exchangeable cations but also their saturation in the complex and the intercational relationships. The $\mathrm{Ca} \%$ of $\mathrm{T}$ in its maximum and minimum values do not change category and remain high. Values greater than $65 \%$ of $\mathrm{Ca} \%$ of $\mathrm{T}$ are considered more appropriate (Hazelton and Morphy, 2007). The $\mathrm{Mg} \%$ of $\mathrm{T}$ changes from non-magnesium to magnesium category but without risk of colloid dispersion, considering the structural state of soil. On the other hand, ideal $\mathrm{Ca} / \mathrm{Mg}$ ratios are reached (2.8). The treatments produced a prolonged effect over time on the absorbent complex, which also has an impact on the soil structure and its stability. Cairo et al., (2017) and Cairo, (2018) using other mineral organ fertilizers with phosphate limestone in Vertisols achieved similar results. Dolomitic or properly dolomite limestone has been studied by researchers such as (Shaaban et al., 2017; Oo et al., 2018) for acid soils with non-dilatable clays in order to correct the acidity and fertility, however in this case, this research is aimed at improving the physical state by guaranteeing a better balance of the cations. (Pedraza, 2005).

\section{Soil structure and consistency}

The impact of dolomitic limestone on an acidic Vertisol and its combination with organic fertilizers on the structure and consistency was analyzed in three dimensions: effects of dolomitic limestone and combinations of dolomitic limestone with organic fertilizers as a function of time, effects of dolomitic limestone levels after 36 months of application, state of the properties under study under the conditions of the experiment at 36 months. The application of $6 \mathrm{tha}^{-1}$ dolomite limestone, showed progressive effect as a function of time in the structure factor, both at the depth of $0-20$ and $20-40 \mathrm{~cm}$, with $R^{2}$ values of 0.85 and $P$ value 0.0000 ( Table 2). Reyes (2007), using dolomitic limestone in acid soils dedicated to coffee production found similar results. On the other hand, the combination of $4 \mathrm{t} \mathrm{ha}^{-1}$ of dolomitic limestone with $15 \mathrm{t} \mathrm{ha} \mathrm{h}^{-1}$ of sugarcane filter cake increased the aggregates as a function of time in the samples of 8, 19 and 36 months of applying the treatment at the same depths. Cairo and Reyes, (2017), in an analysis of the soil physical fertility, pointed out that this depends largely on organ-mineral colloids and the proportion of cations of the absorbent complex. It is interesting to note that not only the residually of the treatments is present, but also its effect on the depth of profile, a matter of great agronomic value so it can represent in the increase of the active soil layer (Cairo, 2018). Vidal et al., (2006) found in studies carried out in these same soils, that one of the limiting edaphic factors to achieve sugarcane yield is the effective depth. Figures 1, 2 and 3 indicated that dolomitic limestone levels increased soil quality and on the other hand reduced the consistency indicators represented by the plasticity index and the liquid limit. This evidenced that dolomitic limestone both alone and in combination with organic fertilizers managed to transform the conditions of plastic and impermeable soil. These results are based on the effect on $\mathrm{pH}$ of biological activity and change in cations relationships (Table 1 ). This ensures a more appropriate water regime and plasticity categories that facilitate tillage. The improvement of the soil physical properties constitutes a very important element in defense of sustainable agriculture (Reyes, 2007; Ogunwole et al., 2014; Cairo and Reyes, 2017).

Table 3 summarizes the effect of dolomitic limestone and organic fertilizers on the soil structure and consistency even after 36 months of applying the treatments. All the indicators evaluated have shown a change of category (Hazelton and Morphy, 2007). Permeability, structure factor and stable aggregates went from the category of regular to excellent, very attributable to the action of the treatments (Cairo et al., 2017; Cairo and Reyes 2017). The liquid limit and the lower plasticity limit behave inversely. Minimum values of the Liquid Limit correspond to the lower plasticity limit and the minimum plasticity index, which determines the change of category from plastic to moderately plastic. Few background results have been found that demonstrate the impacts of improvers such as dolomitic limestone or dolomite on the structure and consistency of Vertisols. Pedraza, (2005) studied the effect of dolomite on the physical and chemical properties of Vertisols and demonstrated the economic feasibility of its application.

\section{Materials and methods}

\section{Description of study area}

The work was carried out on the North coast of the province of Villa Clara, Cuba, Sagua La Grande, in Sugar Cane Experimental Station located at $22^{\circ} 81^{\prime} 19^{\prime \prime} \mathrm{N}$ latitude and $80^{\circ} 03^{\prime} 74^{\prime \prime} \mathrm{W}$ longitude. The soil under study was Vertisols (Soil Survey Staff, 1999). Vertisols are very clayey, but plastic under intense water regime. The local climate is clasisified as Aw according to Köppen. Annual rainfall in the study area is $1150 \mathrm{~mm}$ and average temperature is $25^{\circ} \mathrm{C}$. They are very plastic soils with poor drainage, flat relief. The annual rains reach the value of $1150 \mathrm{~mm}$ on average and the temperatures $25^{\circ} \mathrm{C}$.

\section{Description of experimental design}

The treatments applied were as follows:

T1 Control without fertilization ( $T$ )

T2 NPK 100-60-200 kg ha-1 (NPK)

T3 $2 \mathrm{t} \mathrm{ha}^{-1}$ Dolomitic Limestone

T4 $4 \mathrm{t} \mathrm{ha}^{-1}$ Dolomitic Limestone

T5 $6 \mathrm{t} \mathrm{ha}^{-1}$ Dolomitic Limestone

T6 $4 \mathrm{t} \mathrm{ha}^{-1}$ Dolomitic Limestone $+60 \mathrm{~kg} \mathrm{ha}^{-1} \mathrm{P}$

T7 $4 \mathrm{t} \mathrm{ha}^{-1}$ Dolomitic Limestone $+100-60 \mathrm{~kg} \mathrm{ha}^{-1} \mathrm{NP}$

T8 $4 \mathrm{t} \mathrm{ha}^{-1}$ Dolomitic Limestone + NPK $100-60-200 \mathrm{~kg} \mathrm{ha}^{-1}$

T9 $4 \mathrm{t} \mathrm{ha}^{-1}$ Dolomitic Limestone $+15 \mathrm{t} \mathrm{ha}^{-1}$ Sugarcane filter cake $\mathrm{T} 104 \mathrm{t}$ ha ${ }^{-1}$ Dolomitic Limestone $+4 \mathrm{t} \mathrm{ha}^{-1}$ Compost

The sugarcane variety used was "Cuba 323-68". The experiment was carried out in a total area of $2,726 \mathrm{~m}^{2}$ ( $\left.0.27 \mathrm{ha}\right)$ with 10 treatments and 4 repetitions at a distance between them of $4.0 \mathrm{~m}$. The experimental design was randomized blocks in strips, using plots $7.5 \mathrm{~m} \times 6.4 \mathrm{~m}$ in length and width respectively. The planting distance used was $1.60 \mathrm{~m} \times$ running furrow (10 buds per meter). Two rows $(3.2 \mathrm{~m})$ were left to eliminate the edge effect, for a total of 6 rows per plot. Dolomitic limestone was applied in bands on the furrow, as were the other materials. Three samples were taken at 8,19 , and 36 months, following the same evaluation criteria in all treatments at a depth of $0-20$ and $20-40 \mathrm{~cm}$. 
Table1 Maximum and minimum values and their evaluation of some physical-chemical properties of soil (Sampling at 36 months).

\begin{tabular}{|lllll|}
\hline Properties & Máximum & Category & Mínimum & Category \\
\hline $\mathrm{pH} \mathrm{KCl}$ & 6.70 & Neutral & 4.90 & Medium Acid \\
\hline $\mathrm{pH} \mathrm{H} \mathrm{O}$ & 7.10 & Slightly Alkaline & 5.80 & Medium Acid \\
\hline $\mathrm{Ca} \% \mathrm{~T}$ & 70.77 & High & 60.18 & High \\
\hline $\mathrm{Mg} \% \mathrm{~T}$ & 36.64 & Magnesium & 21.13 & Non- Magnesium \\
\hline $\mathrm{R} \mathrm{Ca} / \mathrm{Mg}$ & 2.58 & Ideal & 1.64 & Low level of Ca with respect to \\
& & & & $\mathrm{Mg}$ \\
\hline $\mathrm{S}$ value cmol $(+) \mathrm{kg}^{-1}$ & 68.26 & & 54.96 & \\
\hline $\mathrm{Ca} \mathrm{cmol}(+) \mathrm{kg}^{-1}$ & 45.40 & Very High & 34.50 & Very High \\
\hline $\mathrm{Mg} \mathrm{cmol}(+) \mathrm{kg}^{-1}$ & 22.35 & Very High & 15.99 & Very High \\
\hline $\mathrm{K} \mathrm{cmol}(+) \mathrm{kg}^{-1}$ & 0.88 & High & 0.21 & Very \\
\hline $\mathrm{Na} \mathrm{cmol}(+) \mathrm{kg}^{-1}$ & 1.81 & Low & 1.21 & Low \\
\hline $\mathrm{N}=80$ & & & & \\
\hline
\end{tabular}

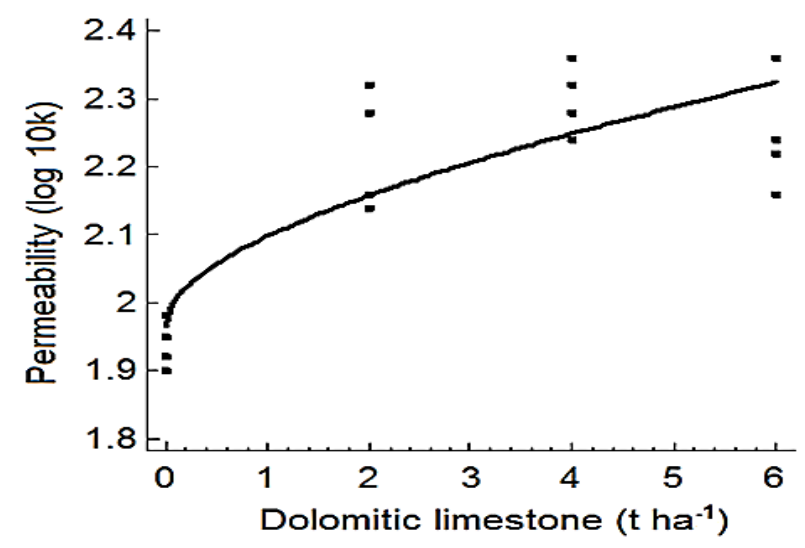

Permeability $=1 /(0.51-0.03 *$ sqrt(treatments) $)$

Figure 1. Effect of the application of different levels of dolomite on permeability (log 10K) after 36 months of application. Depth 0 - 20 $\mathrm{cm} \cdot \mathrm{R}^{2}=75.24$

Table 2. Effect of dolomitic limestone and its combination with organic fertilizers during the 36 months treatments applied treatments. (Samples 8, 19 and 36 months)

\begin{tabular}{|llll|}
\hline Treatments & Correlation Factor & $\mathrm{R}^{2}$ & P Value \\
\hline $6 \mathrm{t} \mathrm{ha}^{-1} \mathrm{DL}^{*}$ & SF $\times$ Time & 0.85 & 0.0000 \\
\hline $15 \mathrm{t} \mathrm{ha}^{-1}$ Sugarcane filter cake+4t ha ${ }^{-1} \mathrm{DL}^{*}$ & SA $\times$ Time & 0.72 & 0.0000 \\
\hline $6 \mathrm{t} \mathrm{ha}^{-1} \mathrm{DL}^{* *}$ & SF $\times$ Time & 0.85 & 0.0000 \\
\hline $15 \mathrm{t} \mathrm{ha}^{-1}$ Sugarcane filter cake+ 4t ha ${ }^{-1} \mathrm{DL}^{* *}$ & SA x Time & 0.62 & 0.0000 \\
\hline
\end{tabular}

DL Dolomitic Limestone SF Structure Factor SA Stable Agregates. *0-20 cm ** $20-40 \mathrm{~cm}$.

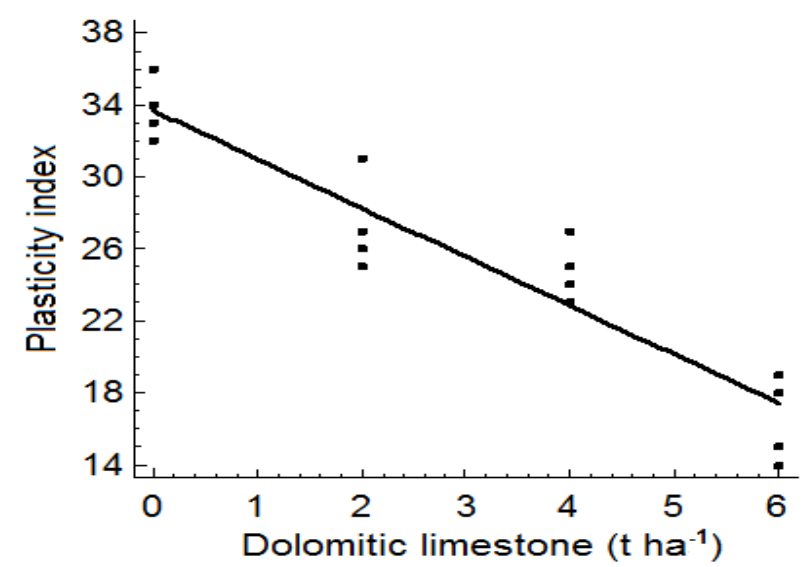

Plastic index $=33.7-2.71 *$ treatments

Figure 2. Effect of the application of different levels of dolomite on the plasticity index 36 months after its application. Depth $0-20 \mathrm{~cm}$. $\mathrm{R}^{2}=88.39$. 
Table 3. Maximum and minimum values and their evaluation of some properties of the soil structure (Sampling at 36 months).

\begin{tabular}{|lllll|}
\hline Properties & Máximum & Category & Mínimum & Category \\
\hline Permeability Log 10K & 2.44 & Excellent & 1.50 & Regular \\
\hline Structure Factor \% & 72.07 & Good & 52.27 & Regular \\
\hline Stable Aggregates \% & 75.59 & Excellent & 54.40 & Satisfactory \\
\hline LL \% & 70.59 & & 50.77 & \\
\hline LPL \% & 38.15 & & 33.18 & \\
\hline PI & 36.64 & Plastic & 13.72 & Moderately Plastic \\
\hline
\end{tabular}

$\mathrm{N}=80$.

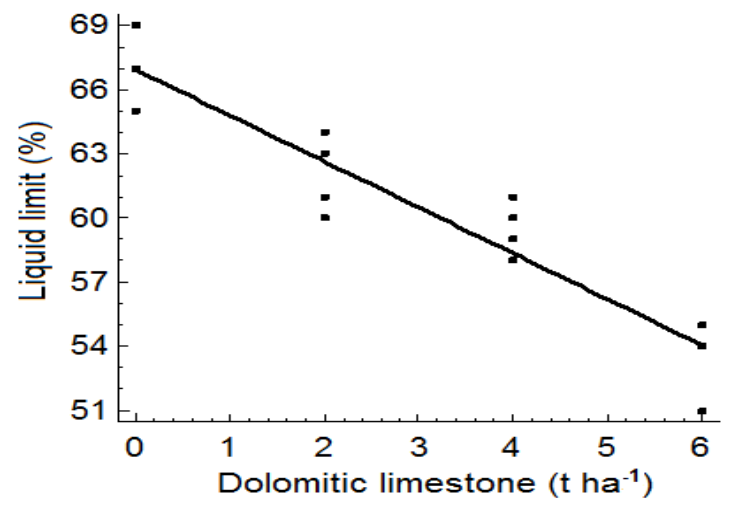

Liquid limit $=66.95-2.15 *$ treatments

Figure 3. Effect of the application of different levels of dolomite on the upper limit of plasticity 36 months after its application. Depth 0 $20 \mathrm{~cm} \cdot \mathrm{R}^{2}=90.20$

\section{Physical analysis}

Soil permeability coefficient (Log $10 \mathrm{~K}$ ) and Stable Aggregates (SA) \% were measured according to the method of Henin et al., (1958). Structure Factor \% (SF) according to Vageler and Alten, (1931). Liquid Limit (LL) \% dry soil base moisture, was determined by the Vasiliev Rocker Cone method. Lower Plasticity Limit (LPL) was determined by the Atterberg roll method (1911) \%. Plasticity Index (PI) determined by the numerical difference between the upper and lower limits.

\section{Chemical analysis}

Soil pH: Potentiometer method (ratio 1: 2.5 soil: $\mathrm{H}_{2} \mathrm{O}$ ); T Value by extraction with ammonium acetate according to Shachtschabel and titration of the sorbed ammonium in a formaldehyde solution and subsequent titration with $0.1 \mathrm{~N}$ sodium hydroxide. $\mathrm{K}+, \mathrm{Na}+$; $\mathrm{Ca}++$; Exchangeable $\mathrm{Mg}++$ by extraction with ammonium acetate according to Shachtschabel and subsequent determination of $\mathrm{K}^{+}, \mathrm{Na}^{+}$by flame photometry and $\mathrm{Ca}^{++}, \mathrm{Mg}^{++}$by complexometry (Versenato). Value $\mathrm{S}$ was equal to sum of the changeable bases $\left(\mathrm{Ca}^{++}, \mathrm{Mg}^{++}, \mathrm{K}^{+}\right.$and $\left.\mathrm{Na}^{+}\right)$.

\section{Statistical procedure}

For statistical processing, the package Statgraphics Plus ver 4.1 was used on Windows 2000. Regressions and correlations were established between the properties studied and adjustment curves with dolomitic limestone levels.

The categories of evaluation of physical and chemical properties in their maximum and minimum values was established according to the criteria of Hazelton and Murphy (2007); Cairo and Reyes, (2017).

\section{Conclusions}

The $\mathrm{Ca} / \mathrm{Mg}$ ratio reached a maximum value of 2.58 , which shows in the effect of the treatments on the interchangeable cations. Dolomitic limestone and its combinations with organic fertilizers showed significant positive effects on soil structure and consistency, both in the surface layer and in the subsoil, with residual impact over time up to 36 months. The results obtained showed a change in the category of structural indicators from regular to excellent (permeability Log10K 1.502.40 ) and the plasticity from plastic to moderately plastic (PI $36.64-13.72)$

\section{Acknowledgments}

The authors thank the Universidad Central de las Villas for the financial help to develop this research

\section{References}

Ayodele OJ, Shittu OS (2014) Fertilizer, Lime and Manure Amendments for Ultisols Formed on Coastal Plain Sands of Southern Nigeria. Agric Forest Fisheries. 3 (6): 481-488.

Atterberg A (1911) Die Plastizität der Tone. Internationale Mitteilungen für Bodenkunde. 1(1):10-43

Cairo P, Reyes A (2017) La fertilidad física del suelo y la agricultura orgánica en el trópico. Editorial Académica Española. ISBN.978-3-659-09006-6. 153p.

Cairo P, Díaz B, Rodríguez A (2017) Soil quality indicators in Vertisols under sugarcane. Arch Agron Soil Sci. 63 (11):14771488. 
Cairo P (2018) Evaluación de la calidad de los suelos Tropicales. Editorial Académica Española. ISBN.978-620-212833-9. 161p.

Damrongrak I, Onthong J, Nilnond C (2015) Effect of fertilizer and dolomite applications on growth and yield of tapping rubber trees. Songklanakarin J Sci Technol. 37 (6): 643-650.

Gina A, Nani S (2013) Effect of dolomite, horse manure and NPK application on plant growth and yield of Cauliflower and its residue effect on Snap bean cultivation. AAB Bioflux. 5 . (2):60-65.

Hazelton P, Morphy B (2007) Interpreting Soil Test Results. What do all the numbers Mean? CSIRO. Publishing. ISBN.9780643092259. Australia.169 p.

Hernández A, Pérez J, Bosch D, Castro N (2015) Clasificación de los suelos de Cuba. Ediciones INCA Cuba, 2015, pp.1-93.

Henin S, Monnier G, Henin S, Combeau A (1958) Method pourl'tude de la stabilite structurale des sols. Ann Agron. 1. 73-92.

Lugones PV, Torres S A (1996) Estudios sobre el efecto de la aplicación de distintas dosis de caliza fosfatada sobre la fertilidad del suelo y la planta. Trabajo de Diploma. Fac. de C. Agropecuarias, UCLV, Santa Clara, Cuba. 63 p.

Nazrul M I, Khan A S M M R (2016) Response of tomato yield to soil test base fertilizer nutrients and levels of dolomite in acidic soil of Sylhet. Sky J of Agric Res. 5(4): 064-068.

Nazrul M I (2018) On-farm verification of dolomite lime and soil test based fertilizer on tuber Yield of potato (Solanum Tuberosum in acidic soils under surma- kushigana floodplain of Bangladesh. Int J Curr Res. 10 (1):64382-64385.

Ogunwole JO, Sharma BR, McCartney MP, Zemadim B, Leta G (2014) Land Use Impact on Soil Physical Quality and Soil Structure in Three Highland Watersheds of Ethiopia. Adv Plant Agric Res. 1(4): 00019.
Oo $A Z$, Sudo $S$, Akiyama $H$, Win KT, Shibata A, Yamamoto A (2018) Effect of dolomite and biochar addition on $\mathrm{N}_{2} \mathrm{O}$ and $\mathrm{CO}_{2}$ emissions from acidic tea field soil. PLoS ONE. 13 (2): e0192235.

Pedraza F (2005) Estudio sobre la efectividad de la dolomita en el mejoramiento de los suelos oscuro plásticos (36 meses después de aplicados los tratamientos). Tesis de Maestría Universidad Central de las Villas. Facultad de Ciencias Agropecuarias. Cuba.110 p.

Reyes A (2006) Indicadores de calidad de suelo en áreas cafetaleras de Topes de Collantes. Tesis presentada en opción al grado científico de Doctor en Ciencias Agrícolas. UNIVERSIDAD CENTRAL "Marta Abreu" DE LAS VILLAS. Santa Clara. 120 p.

Shaaban M, Wu L, Peng Q, Zwieten L, Afzal M, Wu1W, Lin S, Mahmood M, Salman M, Abid M, Hu R (2017) Influence of ameliorating soil acidity with dolomite on the priming of soil $\mathrm{C}$ content and $\mathrm{CO}_{2}$ emission. Environ Sci Pollut Res. 24:92419250.

Vageler P, Alten F (1931) Boden des nils und Gash Zf. Pflanzanernh- Dungung., Boden I. Mitteilung. A 21:47-57.

Velázquez G, Montejo VE, Alfonso E (2013) Alternativas de empleo de las Agromenas en la producción de alimentos. V Convención cubana de Ciencias de la Tierra, Geociencias. Memorias en CD-Rom, 1 al 5 de abril de 2013. La Habana, Cuba, ISSN 2307-49.

Vidal L, Cairo P, Menning P, Könker H, Alonso N, Gutierres A (2006) Slot Drainage of clay soils under sugarcane in Cuba. Irrig and Drain. 55: 511-521. 